Iraqi Journal of Industrial Research (IJOIR)

\title{
Evaluation of Blended NPS Fertilizer Rates and Inter Row Spacing on Yield Components and Yield of Maize (Zea Mays L.)
}

\author{
Abduraman Nure*, Husen Aman Jara \\ Department of Agronomy, Haramaya University, Dire Dawa - Ethiopia
}

\section{Article information \\ Article history: \\ Received: September, 20, 2021 \\ Accepted: October, 03, 2021 \\ Available online: December, 14, 2021}

Keywords:

Fertility,

Grain yield,

Spacing,

Fertilizer

*Corresponding Author:

Abduraman Nure Alisho

abdumone25@gmail.com

DOI:

https://doi.org/10.53523/ijoirVol8I3ID83

\begin{abstract}
Corn is an important cereal crop in Ethiopia due to its use as a source of food security. However, its productivity is limited by insufficient application of the NPS fertilizer and different row spacing. A field trial was carried out to assess the effects of the application of different NPS fertilizer quantities and inter row spacing on the growth, yield components and yield of maize and the cost-benefit analysis of the NPS compound fertilizer application on the yield of maize in the main growing season 2019/2020. The study was arranged in a factorial combination of five levels of NPS fertilizers $(0,50,100,150$ and 200 $\left.\mathrm{kg} \mathrm{NPS} \mathrm{ha} \mathrm{h}^{-1}\right)$ and four inter row spacing $(55 \mathrm{~cm}, 65 \mathrm{~cm}, 75 \mathrm{~cm}$ and 85 $\mathrm{cm})$. in a randomized complete block design with three replications. The consequence showed the main result of the NPS fertilizer had a highly significant ( $\mathrm{p}<0.01$ ) effect on days up to $50 \%$ anthesis, days up to $50 \%$ silk formation, $90 \%$ physiological maturity, leaf area, leaf area index, number of plants at harvest, the number of grains per ear was determined from the main effects of NPS fertilizer of $200 \mathrm{~kg} \mathrm{NPS} \mathrm{ha}^{-1}$. The interaction effects of NPS and row spacing have highly significant ( $p<0.01$ ) effects on the number of ears per plant, number of ears per hectare, ear length, agronomic effectiveness and grain yield were obtained when using $150 \mathrm{~kg}$. measured NPS ha-1 at $75 \mathrm{~cm}$ row spacing. The highest economic (91,608 Birr ha $^{-1}$ ) and a higher MRR (1745\%) resulted from the $150 \mathrm{~kg}$ NPS ha ${ }^{-1}$ and $75 \mathrm{~cm}$ row spacing. Thus, it should be noted that the application of $150 \mathrm{~kg} \mathrm{NPS} \mathrm{ha}^{-1}$ with a row spacing of $75 \mathrm{~cm}$ was both agronomic and cost-effective for the grain yield of the Melkassa-II in the study area.
\end{abstract}

\section{Introduction}

Maize (Zea mays L.) is an indispensable crop in several parts of the developing world. It ranks third after wheat and rice [1]. Providing healthy, safe and sensible food to a growing population is one of the most remote problems Africa is currently facing in order to ensure food security in the region reported AGR [2]. Ethiopia is located in the middle of the countries where corn is grown very heavily and used for various purposes. It ranks second after Teff in terms of area coverage and first in total production and is one of the most important grains that is generally modified worldwide Christian et al [3]. Christian et al [3] also stated that it ranks second after Teff in terms of area coverage and first in total production and is one of the most important grains that is 
generally modified worldwide. It is the top position in grain yield per hectare and is the most productive variety of food crop, and its share is projected to increase by 50\% globally between 1995 and 2020 and $93 \%$ in subSaharan Africa AGR [1].

However, there are a number of factors responsible for the low production and production of corn in Ethiopia. In the midst of these poor agronomic practices such as incorrect seed quantity, row and plant spacing, reduced soil productivity, water shortage, insects, diseases and weeds, farmers' partial access to fertilizers and low right to use seeds of the superior maize variety Shiferaw et al [4]. Fageria and Baligar [5] stated that one of the main problems inhibiting the development of cost-effectively successful agriculture is nutrient deficiency. In many parts of Africa, including Ethiopia, repeated cultivation of land with inappropriate cultivation methods results in drastic reductions in nutrients and soil organic matter, posing a serious threat to agricultural production and sustainability Endris and Dawid [6].

In addition, a lack of appropriate fertilizer mixtures and a lack of micronutrients in fertilizer mixtures are the nationwide difficulties that mainly hamper crop productivity Fufa et al [7]. Requiring necessary plant nutrients in the most favorable amount and correct amount during the correct method and at the correct time of application is the solution for an extended and continuous plant production Cisse and Amar [8]. Chimdessa [9] also reported that mixed fertilizers increased corn production compared to previously available NPs, and the application of real reasonable recommended fertilizer amounts based on soil and plant species is one of the best agronomic practices to utilize the production. Hence, nutrient inputs from chemical fertilizers are desirable to restore nutrients that were stripped and misplaced during cultivation in order to maintain a beneficial nutrient balance Buah and Mwinkaara [10]. Nitrogen is a single component of chemical fertilizers that play an important role in plant life and is one of the most important nutrients that plants want in large quantities. Torbet et al [11] found that the $\mathrm{N}$ application increased the yield and the yield components of corn. It plays an important role in cultural life and is one of the most important nutrients that plants want in large quantities. It is important to know the highest amount of nitrogen in order to get a superior crop yield so that the greatest possible benefit can be achieved.

Many researchers like Samira et al [12] and Torbet et al [11] found that the N application improved the yield and the yield components of corn. similarly Hefny [13] reported that it is one of the most restrictive macronutrients on corn grain yield in the world. The accessibility of nitrogen affects the uptake not only of itself but also of other nutrients Onasanya et al[14], since plants fertilized with $\mathrm{N}$ usually have larger root systems, which improves the uptake of other. On the other hand, in addition to nitrogen, phosphorus and sulfur were also found to be extremely low in the most important Ethiopian soils studied Bellete [15]. This is due to the degradation of organic material, the depletion of macro and micronutrients, soil acidity, erosion of topsoil and the decline in physical soil properties Zeleke et al [16].

Phosphorus is an additional vital element that increases corn production Chen et al [17]. Therefore, the lack of phosphorus is just as important in the restrictive corn routine as the lack of nitrogen. The importance of phosphorus as a yield-limiting reason in several Nigerian soils is well documented Adeptu [18]. Similarly, sulfur is known as the fourth major nutrient after N, P and $\mathrm{K}$. On average, maize takes in as much S as P. Its deficiency has consequences for underdeveloped growth, compacted plant height, tillering, spike lets and late ripening. If there is a $\mathrm{S}$ deficiency in the soil, the full yield potential of the crop cannot be realized regardless of other nutrients, even with good crop cultivation practice Tandon [19]. It is mandatory for the synthesis of S-containing amino acids like cysteine and methionine. Plant thickness is also one of the most important cultural practices affecting grain yield, as well as other significant agronomic properties of that culture Sangoi [20].

The stand density influences the structural design of the plants, changes growth and development patterns and influences the production and distribution of carbohydrates Casal et al [21]. Therefore, maize does not share the property of most tillers to compensate for low leaf areas and low number of reproductive units by branching Gardner et al [22]. Anjum et al [23] reported that grain yield increased with increasing compactness of the plants, until the production factors were no longer limiting. 
The most favorable spacing between and between rows increased cob-1 kernel count, kernel weight to 1000, and corn yield Sabir et al [24]. Mahmood et al [25], also showed that the largest grain yield of 6.6 tones ha-1 maize was achieved at close spacing alongside the minimum $3.28 \mathrm{t} \mathrm{ha}^{-1}$, although close plant spacing $(55 \mathrm{~cm})$ was a significant reduction of the production apparatus, like grain and 1000, caused significant part weights compared to the large distances between the plants.

Haramaya, where the study was conducted, is one of the corn growing areas in the East Hararghe Zone in eastern Oromia, Ethiopia. In the region, maize production is of particular importance in the main harvest season; Since there is a high demand for grain and new corn on the cob, stalks are used as animal feed and fuel. The gab in the study district was that the bulk of the farmers where not apply most beneficial fertilizer level, suitable spacing when they make maize HANRO [27]. It is therefore necessary to make area-specific suggestions for the mixed NPS fertilizer rate and the row spacing in order to achieve the highest and most advanced maize yield. Therefore, the study was carried out with the aim of: -Deciding the cause of mixed NPS fertilizer quantities and row spacing on yield equipment and maize yield and weighing up the cost advantage of mixed NPS fertilizer quantities in maize grain production.

\section{Theoretical Part}

\section{Description of the Study Area}

The field tests were carried out in the Haramaya district. Haramaya is located on the eastern escarpment of the Rift Valley at $9^{\circ} 26$ 'north latitude and $42^{\circ} 03^{\prime}$ east longitude and an altitude of 1,400 to $2026 \mathrm{~m}$. It is located in the semi-arid tropical safe east of Ethiopia and is characterized by a sub humid climate with an average annual rainfall of about 600 to $1,260 \mathrm{~mm}$, the minimum and maximum mean annual temperatures are $9.59{ }^{\circ} \mathrm{C}$ and 24.15 ${ }^{\circ} \mathrm{C}$. Haramaya University [28]. The area's rainy season is bimodal; the small rainy season began from March to May and the main rainy season from July to September Tekalign and Hammes [29]. The soil of the test area is classified as Fluvisols.

\section{Soil Sampling and Analysis}

To illustrate the soils of the study area, surface soil samples were taken from a distance of $0-30 \mathrm{~cm}$ down in a criss-cross pattern using an auger based on the methods described by Munson and Nelson [30] from five random locations in each block of the study field prior to sowing, assembled, air-dried in the shade, packaged and labelled, and one (1) kg of the pooled sample was sent to the Haramaya University soil laboratory. The samples submitted were used to analyze soil cation exchange capacity (CEC), organic carbon, available phosphorus, total nitrogen (\%), exchangeable bases $\left(\mathrm{Na}^{+}, \mathrm{K}^{+}, \mathrm{Ca}^{++}\right.$, and $\left.\mathrm{Mg}^{++}\right)$, soil texture class and soil $\mathrm{pH}$ a standard laboratory uses procedures.

The total nitrogen in the soil was determined by the Kjeldahl method [31] and the soil phosphorus was predictable by the Olsen method [32]. Soil organic carbon was determined using Walkley and Black [33]. Accessible sulfur was determined using the cloudy metric method Chesnin and Yein [34], while soil texture was determined by the Bouyoucos [35]. The $\mathrm{pH}$ of the soil was probably in a soil-water suspension (1: 2.5) with the help of a $\mathrm{pH}$ meter. The soil CEC was determined by the ammonium acetate method Cottenie [36].

\section{Experimental Procedure}

\section{Treatment and Experimental Designs}

The treatments contain five quantities of mixed NPS $\left(0,50,100,150\right.$ and $200 \mathrm{~kg}$ NPS ha $\left.{ }^{-1}\right)$ and four row spacing's $(55 \mathrm{~cm}, 65 \mathrm{~cm}, 75 \mathrm{~cm}, 85 \mathrm{~cm})$. The experiments were carried out in a randomized complete block design (RCBD) in a factorial arrangement and replicated three times. So here $5 \times 4=20$ treatment combinations form 60 plots. There were five rows for $85 \mathrm{~cm}$ and $75 \mathrm{~cm}$ row spacing, six rows for $65 \mathrm{~cm}$ spacing and seven rows for $55 \mathrm{~cm}$. The distance between the plants is $30 \mathrm{~cm}$, near plots and blocks were divided by $1 \mathrm{~m}$ and $1.5 \mathrm{~m}$ respectively. Statistics were collected from the middle rows without a row from each side of the plot and a plant from either end of the row.

\section{Experimental Procedure and Field Management}

Before sowing, the land was well prepared by frequent tractor plowing three times. Parcels were leveled; Furrows and ridges were prepared. There were 39, 215, 44, 444, 44,444, 51283 and 60606 plants per hectare, 
correspondingly under $85 \mathrm{~cm}$ x $30 \mathrm{~cm}, 75 \mathrm{~cm}$ x $30 \mathrm{~cm}, 65 \mathrm{~cm}$ x $30 \mathrm{~cm}$ and 55 x $30 \mathrm{~cm}$ row spacing. whereas one plant in both row ends under the entire row spacing was measured as border plants. Corn seeds were grown according to the planned row spacing. Initially, two seeds were planted per hill and later thinned out to a plant over a period of 3 to 4 leaves.

At the time of planting, all plots received an NPS mixed fertilizer with a basal function $(19 \% \mathrm{~N}, 38 \%$ P2O5 and $7 \% \mathrm{~S}$ ). However, $46 \mathrm{~kg} \mathrm{~N}$ ha-1 in the form of urea in the knee stage. The nitrogen was placed at knee level about $5 \mathrm{~cm}$ from the plant base. Any additional agronomic practices, similar to hoeing, weeding, were useful for all treatments proposed for corn.

\section{Crop Data Collection and Measurement \\ Crop phenological data}

Days to $50 \%$ anthesis: the number of vital days from sowing to the start of pollen release in $50 \%$ of maize plants

Days to 50\% silking: It was the number of days in use from the date of planting to the stage when $50 \%$ of the plants showed silk extrusion.

Days to $90 \%$ physiological maturity; Recorded when $90 \%$ of the plants in a net had matured physiologically (the kernels formed a black layer on the base of the germ at the point of attachment of the kernel to the ear).

\section{Growth parameter}

Leaf area: all accessible leaves of five plants per net plot were recorded at the $50 \%$ milking stage and the leaf length and width were calculated and the leaf area was calculated as follows: Leaf area = maximum leaf length $(\mathrm{cm}) \mathrm{x}$ maximum width $(\mathrm{cm})$ and adjusted by the correction factor $(0,75)$ as recommended by [38].

Leaf area index: It was calculated as the percentage of the total leaf area per five plants $(\mathrm{cm} 2)$ per land area occupied by the plants Diwaker and Oswalt [39].

Plant height: It was calculated as the height from the soil surface to the base of the tassel of five plants taken at random from the net plot area at $75 \%$ physiological maturity.

\section{Yield and yield component}

Stand count: The number of stands per plot was recorded from the net plot area after thinning and during harvest. The final plant stand percentage (final plant stand number at maturity / population, determined after thinning $x$ 100) of the respective treatments was used to determine the stand loss due to treatments with closer spacing.

Number of ear per plant: It was recorded from the five randomly used plants in the central net plot area at harvest.

Number of ear per hector: It was recorded by counting the number of ears of corn per plot and converting it to hector.

Ear length: It was recorded from the calculation of ten randomly picked ears per net plot at harvest.

Number of kernel per ear: It was recorded from the middle of five randomly picked ears per plot. This was done by manually peeling and counting the normal grains and then averaged per plant

Thousand grain yield: One thousand kernels were counted from a mass of peeled kernels from the net plot and weighed using a sensitive balance and the weight was adjusted to a moisture content of $12.5 \%$.

Above ground dry biomass: It was recorded from five plants per net plot and was weighed during harvesting and the result was converted to tons per hectare 
Grain yield: It was determined from the net plot area and the result was converted to tons per

Harvest index: It was viewed as the ratio of grain yield to aboveground dry biomass per net plot and multiplied by 100 .

\section{Economic Analysis}

Economic analysis was done using the method described by CIMMYT [41]. The variable costs including the seed, NPS blended fertilizer, labor cost price at time of planting (May 2019) and the price of the inputs at planting (May 2019), together with the cost of seed (65.00 ETB kg-1), NPS fertilizer (18.00 ETB kg-1), Urea (16.00 ETB kg $\mathrm{g}^{-1}$ ) at the time of planting (May 2019) and according to Haramaya, farm on a daily basis payment of labor cost for use of NPS (5 persons ha ${ }^{-1}$, each 75 ETB day ${ }^{-1}$ ). The costs of other inputs and production practices such as labor cost for land preparation, planting, weeding, and harvesting, transportation, guard, was consider the same for all treatments or plots. The average yield accustomed down by $10 \%$ to reflect the farmers yields as illustrated CIMMYT [41].

Unadjusted grain yield (UGY) (grain yield $\left.\mathrm{ha}^{-1}\right)$ : is an average yield of each treatment

Adjusted grain yield (AGY) (grain yield ha ${ }^{-1}$ ): is the average yield adjusted downward by a 10\% to reflect the difference between the trial yield and yield of farmers.

Gross field benefit (GFB) $\left(\mathrm{ETB} \mathrm{ha}^{-1}\right.$ ): was computed by multiplying field/farm gate price that farmers receive for the crop when they sell it as adjusted yield. GFB = AGCY field/farm gate price for the crop.

Total variable cost (TVC) $\left(\mathrm{ETB} \mathrm{ha}^{-1}\right)$ : was calculated by dividing the different costs together with the costs for the fertilizers of the varieties Seed Melkassa-2 (65.00 ETB kg-1), NPS (18.00 ETB kg-1) and urea (16.00 ETB $\mathrm{kg}^{-1}$ ) at the time of planting (May 22, 2019) and according to Haramaya, daily payment of the farm's labor costs for the application of NPS (8 people ha ${ }^{-1}, 75$ ETB day $^{-1}$ each).

Net benefit (NB) (ETB ha ${ }^{-1}$ ): was calculated by subtracting the total uneven costs (TVC) from gross field benefits (GFB) for each treatment. NB $=$ GFB - TVC

Dominance analysis: was performed by first listing all treatments in order of increasing costs that vary (TVC) and then setting aside their net benefits (NB). Any treatment with a higher TVC but a net benefit that is less than or equal to the previous treatment (with a lower TVC but higher net benefit) becomes a dominated treatment (marked with a D).

Marginal rate of return (MRR) (\%): was calculated by dividing the change in net benefit (NB) by the change in total variable cost (TVC) times one hundred.

\section{Statistical Data Analysis}

The collected data were subjected to an analysis of variance (ANOVA), which is suitable for the factorial experiment in RCBD according to the General Linear Model (GLM) of GenStat 16th Edition [42]. The interpretations were made according to the procedure described by Gomez and Gomez. The differences between treatment means were compared using the Least Significant Difference (LSD) test at a level of significance of 5\% when ANOVA showed the presence of a significant difference were compared using Least Significant Difference (LSD) test at 5\% level of significance when the ANOVA showed the presence of significant difference.

\section{Results and Discussion}

\section{Soil Physico-chemical Properties of the experimental Site}

Physical and chemical properties of the soil were analyzed for the soil sample $(0-30 \mathrm{~cm}$ deep $)$ from the test field. The results of the analysis of the physical properties of the soil showed that the sand, silt and clay contents are about $62 \%, 3 \%$ and $30 \%$, respectively (Table 1). Thus, the texture of the soil was sandy-clay loam according to the Bouyoucos [43] classification. The texture shows the degree of weathering, the nutrient and water retention 
capacity of the soil. The high clay content could indicate a high water retention capacity of the soil in the study area.

The cation exchange capacity is the capacity of the soil to take up and replace cations. The cation exchange capacity of a soil was a measure of the degree of negative charge per unit weight of soil, or the amount of cations that a given soil sample could hold in exchangeable form. Cation The result showed that the cation exchange capacity of the experimental soil was $34 \mathrm{cmol}^{(+)} \mathrm{kg}^{-1}$ or (meq / $100 \mathrm{~g}$ soil) (Table 1). Landon [44] classified CEC of $\langle 6,6-12,12-25,25-40\rangle ,40 \mathrm{cmol}(+) / \mathrm{kg}$ as very low, low, moderate, high and very high, respectively. Therefore, the CEC of the research location is rated as high. Murphy [45] classified the organic carbon content in the soil of $<0.60,0.61 .0,1.01 .80,1.803 .0$ and $>3$ as very low, low, medium, high and very high.

Therefore, organic carbon content of the soil was $0.736 \%$ which was low according to the rating of Murphy [45] indicating low potential of the soil to supply nitrogen to plants through mineralization of organic carbon. Therefore, the soil had very low organic carbon content. Total nitrogen measures the total amount of nitrogen found in the soil, much of which is held in organic matter. The result of the analysis showed that the total nitrogen content was $0.05 \%$ (Table 1). Tekalign and Hammes [29] classified the total $\mathrm{N}$ availability in the soil of $<0.1 \%$ as very low, $0.1-0.2 \%$ low, $0.2-0.5 \%$ as moderate, $0.5-1$ high and $>1 \%$ as very high.

Therefore, the total nitrogen of the research location is rated as very low. Therefore, the soil of the research site has a very low total nitrogen content and requires nitrogen application, since maize is a very depleted crop for nitrogen and its production potential is strongly influenced by N. The final result of the analysis also indicated that the available $\mathrm{P}$ content in the research area was $11.9 \mathrm{ppm}$ soil. Tekalign and Hammes [29] described soils with available $\mathrm{P}<10,11-31,32-56,>56 \mathrm{ppm}$ as low, medium, high or very high. Therefore, the result showed that the total amount of available soil P content is medium. The sulfur available in the soil was $3.12 \mathrm{ppm}$; therefore the result showed that the available sulfur content is low according to the classification of EthioSIS EthioSIS [46]. Although the soil was suitable for maize production, it had to be applied in organic nitrogen by various methods because of its limited availability and its high tendency to mobility and loss. The soil's available sulfur content was also very low and its available phosphorus was medium and this was mitigated by the application of inorganic sulfur and inorganic phosphorus in the form of mixed NPS fertilizers for better production.

\section{Phenological and Growth Parameters Days to 50\% anthesis}

Days up to $50 \%$ anthesis were highly significantly $(\mathrm{p}<0.01)$ influenced by the main effects of the mixed NPS fertilizer quantities and the row spacing. However, the interaction effect of the mixed NPS fertilizer amounts and the distance between the rows showed no significant effect on days up to 50\% and thesis. It was practical that the mixed NPS fertilizer amount increased from $0 \mathrm{~kg} \mathrm{NPS} \mathrm{ha}^{-1}$ to $200 \mathrm{~kg} \mathrm{NPS} \mathrm{ha}^{-1}$ days until the anthesis of (77 to 82.12). This delay in days to anthesis with the mixed NPS fertilizer could be attributed to the influence of the positive interaction of nitrogen with other nutrients in the mixed NPS fertilizers, which promoted more vegetative growth and greater photosynthesis than reproductive parts. This is in line with the results of Mekdad [47] reported that nitrogen plays multiple roles in plant metabolism, and to positively achieve these roles it should positively interact with other essential nutrients and increase the photosynthetic efficiency of corn. With a row spacing, the first days up to $50 \%$ anthesis (77.80 days) were obtained from a row spacing of $55 \mathrm{~cm}$ and the late days up to anthesis ( 81.20 days) from a distance of $85 \mathrm{~cm}$. However, the early anthesis with less row spacing could be due to strong competition between plants for growth resources, which may have accelerated the days to anthesis. In agreement with these results, Abdulatif [49] also indicated that maize required longer mean flowering days with a lower population density of $\left(30,952\right.$ plants ha $\left.{ }^{-1}\right)$, followed by the mean $\left(34,111\right.$ plants ha $\left.^{-1}\right)$ maize plant density. comparable to this effect, Hamid and Nasab [50] showed that increases in plant densities and the duration of the vegetative and reproductive period are significantly delayed, denser populations comparatively shorter periods than those that were planted with lower density. 


\section{Days to 50\% silking}

Analysis of variance showed that the main effects of the mixed NPS fertilization rates and the distance between the rows were highly significant $(\mathrm{p}<0.01)$ on days up to $50 \%$ silk effect, while the interaction effect was not significant.

Any factor that affects silking can affect grain production directly. As the rate of blended NPS fertilizer rises from $0 \mathrm{~kg} \mathrm{ha}^{-1}$ to $200 \mathrm{~kg} \mathrm{ha}^{-1}$, the days to silking was increased from (81.25 days to 86 days). Delayed silking in higher blended NPS fertilizer rates might be owing to $\mathrm{N}$ fertilizers in the blended attributed to vigorous vegetative growth and increased light use effectiveness. In conformity with this result, Wakjira [51] indicated that increasing the rate of NPS from $0 \mathrm{~kg} \mathrm{ha}^{-1}$ to $200 \mathrm{~kg} \mathrm{ha}^{-1}$ postponed days to $50 \%$ silking from 71.50 to 76.42 . Likewise Imran et al [52] also described that increasing $\mathrm{N}$ rate to $210 \mathrm{~kg} \mathrm{ha}^{-1}$ application postponed silking in maize by 5 days compared to control treatment.

Similarly Treatments with higher nitrogen levels took more days to form silk Akbar et al [53]. Days up to 50\% silk formation were highly significantly $(\mathrm{p}<0.01)$ influenced by the main effect of row spacing. The highest days up to $50 \%$ silking were recorded with increasing row spacing, with the highest days up to silking (84.07 days) being recorded at $85 \mathrm{~cm}$ row spacing, while the narrowest row spacing of $55 \mathrm{~cm}$ was recorded at the earliest in days up to silking $(81,80)$ was days).

The delayed silk formation in the larger distances could be due to a lower plant density, which increased less competition for growth factors, more vegetative growth, which ultimately delayed the days until silk formation. Similarly, with increasing plant density from 57,000 plant ha $^{-1}$ to 99,000 plant ha $^{-1}$, the number of days until $50 \%$ silk formation was delayed in four days and the longest days until silking $(53,38)$ was obtained 99,000 plant ha $^{-1}$ Mahmood et al [25].

\section{Days to $90 \%$ physiological maturity}

The main effects of NPS fertilization have a highly significant $(\mathrm{p}<0.01)$ influence on the days to physiological maturity. However, the main effect of the row spacing and the interaction had no significant influence on days to a physiological maturity of $90 \%$. The days until physiological maturity are directly related to the days up to $50 \%$ tassel and days up to 50\% silk. The maximum days to physiological maturity (128.8 days) were recorded from the plot that received $200 \mathrm{~kg}$ of NPS ha-1. However, there is no significant difference in the days to physiological maturity (125 days) recorded for the treatment grown under $150 \mathrm{~kg} \mathrm{NPS} \mathrm{ha}^{-1}$, while the lowest days to maturity (122.2 days) for treatment without fertilizer were recorded.

As NPS rates were extended by days to physiological maturity, this could be due to the sulfur and nitrogen in the mixed fertilizer, which motivates the enzymatic actions, as well as chlorophyll formation, which increases the amount of solar radiation intercepted, which affects growth parameters and promotes the development of the plants Sanchez et al [54] and consequently increases the days until flowering and physiological maturity.

Application of $\mathrm{N}$ postponed leaf senescence, sustained leaf photosynthesis during active crop growth stage and extended the duration of vegetative growth and it clearly indicated that ever-increasing NPS The application of $\mathrm{N}$ delayed leaf aging, sustained leaf photosynthesis during active plant growth and prolonged the duration of vegetative growth and it clearly showed that constantly increasing NPS values have a decisive influence on growth, development and yield. This product was also similar to the results from The highest days to the hard dough stage (150.3 days) were recorded at $150 \mathrm{~kg} \mathrm{NPS} \mathrm{ha}^{-1}$, while the earliest days to the stage were recorded hard dough (139.8 days) were recorded for no NPS application (control) Alemayo [55].

In the same way, Dinkinesh [56] reported that the highest number of days required for $90 \%$ physiological maturity (104.5 days) at the highest rate of NPSB compound feed (183 kg NPSB ha $\left.{ }^{-1}\right)$ was recorded, while the control (0 kg NPSB) showed the shortest growth time of days up to $90 \%$ physiological maturity (99 days) for durum wheat. [48] also reported that with the increase in nitrogen rates from 0 to $128 \mathrm{~kg} \mathrm{~N} \mathrm{ha}^{-1}$, the days up to physiological maturity of maize were also consistently lengthened from 130.08 to 135.5 days.

\section{Leaf area and leaf area index}

The analysis of variance showed that both the mixed NPS rate and the distance between the rows had a highly 
significant ( $\mathrm{p}<0.01)$ effect on the leaf area and the leaf area index (Table 1).

however, the interaction effect of mixed NPS fertilization rates and row spacing showed no significant influence on the leaf area and the leaf area index of maize in this study.

The highest leaf area of the plant $\left(8620 \mathrm{~cm}^{2}\right)$ and the leaf area index (4.157) were obtained at the highest mixed fertilizer amount $\left(200 \mathrm{~kg} \mathrm{ha}^{-1}\right)$ and the values were statistically equal to the mixed NPS fertilizer amount of 150 $\mathrm{kg} \mathrm{ha}^{-1}$ whereas the lowest Leaf area $\left(7519 \mathrm{~cm}^{2}\right)$ and leaf area index (3.61) were recorded without mixed NPS fertilization (Table 1).

The end result is in line with Jeet et al [57] who reported that $\mathrm{N}$ is closely involved in the metabolism of plants, which is essential for achieving optimal leaf area, the main indicator of the size of the assimilation system in maize, which is maximized Harvesting the incident solar radiation. Likewise, the effects of high phosphorus levels on growth parameters may have been due to better root system development and nutrient uptake Masood et al [58]. On the other hand, $\mathrm{N}$ deficiency in plants can significantly reduce protein synthesis. In addition, the leaf area and the canopy architecture as well as the rate of photosynthesis of the leaves determine the rate of dry matter accumulation in the corn crown. Consistent with this result, Wakjira [51] reported that an increase in the NPS rate from $0 \mathrm{~kg} \mathrm{ha}^{-1}$ to $200 \mathrm{~kg} \mathrm{ha}^{-1}$ leaf area increased from $6785.5 \mathrm{~cm} 2$ to $8097 \mathrm{~cm}^{2}$. Applied P increased leaf appearance rate, final leaf count, and leaf area per plant Guterrez and Thomas[59].

Similarly, Sakal et al [60] reported that the leaf area index, plant height and dry matter production of maize increased significantly with increasing sulfur content up to $60 \mathrm{~kg} \mathrm{~S} \mathrm{ha}^{-1}$. The highest leaf area per plant $(8463$ $\mathrm{cm}^{2}$ ) was obtained from the row spacing of $85 \mathrm{~cm}$ and was statistically the same with the row spacing of $75 \mathrm{~cm}$, while the lowest leaf area $\left(7557 \mathrm{~cm}^{2}\right)$ was measured under the narrowest intermediate row spacing of $55 \mathrm{~cm}$ (Table 1).

In contrast to leaf area, the closest row spacing of $55 \mathrm{~cm}$ resulted in a maximum leaf area index (4.617), while the lowest leaf area index (3.680) was recorded below the widest row spacing of $85 \mathrm{~cm}$ (Table 1).This result agreed with Lakew et al [61], who reported the highest leaf area per plant of $7338.4 \mathrm{~cm} 2$, was obtained from the widest row spacing of $30 \mathrm{~cm}$, while the lowest $(6732.3 \mathrm{~cm} 2)$ was measured at the narrowest row spacing of 20 $\mathrm{cm}$ maize. In addition, Sangoi[62] showed that with a row spacing of $75 \mathrm{~cm}$ a larger leaf area of maize $(7258$ $\mathrm{cm}^{2}$ ) was achieved than with $50 \mathrm{~cm}\left(6118 \mathrm{~cm}^{2}\right)$.

Table (1). Main effect of blended NPS fertilizer rate and inter-row spacing on leaf area and leaf area index of maize.

\begin{tabular}{lll}
\hline NPS fertilizer rates $\left(\mathrm{kg} \mathrm{h}^{-1}\right)$ & Leaf Area of plant $\left(\mathrm{cm}^{2}\right)$ & Leaf Area Index \\
\cline { 2 - 3 } 0 & $7519^{\mathrm{e}}$ & $3.610^{\mathrm{c}}$ \\
50 & $7874^{\mathrm{d}}$ & $3.826^{\mathrm{c}}$ \\
100 & $8164^{\mathrm{c}}$ & $3.997^{\mathrm{c}}$ \\
150 & $8470^{\mathrm{b}}$ & $4.097^{\mathrm{b}}$ \\
200 & $8620^{\mathrm{a}}$ & $4.157^{\mathrm{a}}$ \\
\hline LSD (0.05) & 42.68 & 0.2482 \\
\hline Inter-row spacing (cm) & & \\
55 & $7557^{\mathrm{d}}$ & $4.617^{\mathrm{a}}$ \\
65 & $8109^{\mathrm{c}}$ & $4.153^{\mathrm{b}}$ \\
75 & $8392^{\mathrm{b}}$ & $3.680^{\mathrm{c}}$ \\
85 & $8463^{\mathrm{a}}$ & $3.680^{\mathrm{c}}$ \\
\hline LSD (0.05) & 42.68 & 0.2220 \\
\hline CV (\%) & 1.8 & 2.3 \\
\hline
\end{tabular}

$* *=$ Significant at 1\% probability levels; LSD = Least Significant Difference; CV=Coefficient of Variation. Means in columns and rows followed by the same letters are not significantly different at $5 \%$ level of significance. 


\section{Plant height}

The main effect of NPS fertilization and the interaction of NPS and row spacing were highly significant (p $<0.01$ ) on plant height, while the main effect of row spacing was no change on plant height (Table 2). The tallest plant $(246 \mathrm{~cm})$ was obtained for a combination of $55 \mathrm{~cm}$ and $200 \mathrm{~kg} \mathrm{NPS} \mathrm{ha}{ }^{-1}$, while the shortest plant $(184 \mathrm{~cm})$ came from $55 \mathrm{~cm}$ and $0 \mathrm{~kg}$ NPS ha ${ }^{-1}$.

When the amount of mixed NPS was increased from 0 to 200 NPS, the ha ${ }^{-1}$ plant height was increased at most of the inter-row spacing. The result apparently indicated that the plant height was increased in response to the increased levels of the NPS fertilizer. This percentage increase in plant height could be due to an increase in cell elongation and increased vegetative growth due to different levels of nutrients that include NPS and macronutrients. On the other hand, the lowest plant height in unfertilized plots could be due to the low fertility of the soil in the study area. Consistent with the results of this study, plant growth and development can be significantly retarded if one of the nutrient elements in the soil is below its threshold or is not adequately balanced with other nutrient elements Landon [44].

Thus, the results show that the application of mixed fertilizers improved the vegetative growth of corn. Plant height increased with increasing $\mathrm{N}$, which could be attributed to the mere fact that higher levels of nitrogen may have caused rapid cell division and elongation Shamim et al [64].

This result was in agreement with Workayehu [65] who found that $\mathrm{P}$ and $\mathrm{N}$ fertilizers have a significant impact on corn plant height. Likewise, Chimdessa [9] reported that the use of mixed fertilizers significantly increased the plant height of corn compared to the recommended NP. [66] also reported that the application of N and P fertilizers increased the plant height of bread wheat and recorded the highest heights of 94.18 and $90.56 \mathrm{~cm}$ with applications of $69 \mathrm{~kg} \mathrm{~N} \mathrm{ha}^{-1}$ and $30 \mathrm{~kg} \mathrm{P}$, respectively ha ${ }^{-1}$.

Consistent with this finding, Tilahun and Tamado [67] also reported that the maximum application rate of mixed NPS $\left(200 \mathrm{~kg} \mathrm{ha}^{-1}\right)$ resulted in wheat with the highest plant height $(79.59 \mathrm{~cm})$. [68] also reported a significant effect of $\mathrm{N}$ fertilizer on corn plant height in a similar manner; increasing P-rates from 0 to $53.2 \mathrm{~kg} \mathrm{P}^{\mathrm{h}} \mathrm{ha}^{-1}$ also increased plant height. Similar report that the highest corn crop was grown on the combined treatments of $90 \mathrm{~kg}$ $\mathrm{N}$ and $30 \mathrm{~kg} \mathrm{~S} \mathrm{ha}^{-1}$, showing a 148.65\% increase over the control Habtamu [69]. With row spacing, a high plant density leads to certain changes in plant growth, such as more sunlight Singh and Singh [70]. The result also agreed with the observation by Goldsworthy and Taylor [71], who reported an increase in sorghum height with increasing plant density. Consistent with the result, Mathews et al [72] reported that maize planted with a plant spacing of $25 \mathrm{~cm}$ and a row spacing of $50 \mathrm{~cm}$ had significantly taller plants than those planted with a plant spacing of $30 \mathrm{~cm}$ and a row spacing of $75 \mathrm{~cm}$. The increase in plant height with narrower row spacing could be due to a comparatively low level of solar radiation through the plant roof at narrow spacing (high plant density).

Table (2). Interaction effects of blended NPS fertilizer rates and inter row spacing on plant height (m) of maize.

\begin{tabular}{|c|c|c|c|c|c|}
\hline \multicolumn{2}{|c|}{ NPS rates $\left(\mathrm{kg} \mathrm{ha}^{-1}\right)$} & \multicolumn{4}{|c|}{ Inter row Spacing $(\mathrm{cm})$} \\
\hline & & 55 & 65 & 75 & 85 \\
\hline \multicolumn{2}{|l|}{0} & $1.8400^{\mathrm{a}}$ & $2.2167^{b}$ & $2.2500^{c}$ & $2.350^{\mathrm{ef}}$ \\
\hline \multicolumn{2}{|l|}{50} & $2.2500^{c}$ & $2.2567^{c}$ & $2.3267^{\text {de }}$ & $2.350^{\mathrm{ef}}$ \\
\hline \multicolumn{2}{|l|}{100} & $2.3600^{f}$ & $2.3533^{f}$ & $2.3133^{d}$ & $2.4000^{\mathrm{hi}}$ \\
\hline \multicolumn{2}{|l|}{150} & $2.4167^{\mathrm{ij}}$ & $2.3433^{\text {ef }}$ & $2.3633^{\mathrm{fg}}$ & $2.3867^{\text {gh }}$ \\
\hline \multicolumn{2}{|l|}{200} & $2.4633^{k}$ & $2.4367^{\mathrm{j}}$ & $2.4000^{\mathrm{hi}}$ & $2.3567^{\text {gh }}$ \\
\hline LSD (0.05) & 0.384 & & & & \\
\hline CV (\%) & 9.9 & & & & \\
\hline
\end{tabular}

LSD = Least Significant Difference; CV= Coefficient of Variation. Means in columns and rows followed by the same letters are not significantly different at $5 \%$ level of significance. 


\section{Yield Components and Yield of Maize}

\section{Plant stand count percent at harvest}

Analysis of variance showed that the percentage of stand count numbers was highly significantly $(\mathrm{P}<0.01)$ influenced by the main effects of the NPS compound fertilizer amounts and the level of row spacing, but their interaction was not significant (Table 3). The highest percentage of stand counts at harvest (96.657\%) was recorded for NPS mixed quantities at $200 \mathrm{~kg} \mathrm{ha}^{-1}$, while the lowest percentage of stocks at harvest $(92.28 \%)$ was measured without NPS application.

The highest percentage of stand count at harvest (96.657\%) was recorded for NPS mixed quantities at $200 \mathrm{~kg}$ $\mathrm{ha}^{1}$, while the lowest percentage of stand count at harvest $(92.28 \%)$ was measured without NPS application The increase in stocks at harvest when the NPS compound fertilizer amounts and the spacing between rows are increased could be due to the positive interaction of macronutrients in the mix (NPS) and the balanced use of nutrients necessary for the increase in stand count at harvest are responsible for the harvest.

The highest stand count could be due to adequate root initiation, which strengthens the anchoring of the seedlings, while the lowest stand count is due to mortality from lack of nitrogen, phosphorus and sulfur fertilizers. In line with that Brady and Weil [73] reported that nitrogen-deficient plants develop thin and spindly stems that could be exposed to lodging by wind. In addition, plants poor in $\mathrm{N}$ and $\mathrm{P}$ have reduced development of the root system, which reduces their anchoring capacity.

Consistent with these results, Kena [74] reported that the number of plant stands increased from $90.39 \%$ to $98.26 \%$ by increasing the intermediate rows from $55 \mathrm{~cm}$ to $85 \mathrm{~cm}$. Similarly, Eskandarneja et al [75] reported that due to the wider distance combinations of $75 \mathrm{~cm}$ x $30 \mathrm{~cm}$, a higher number of plants (98\%) was achieved than the narrower distance of $55 \mathrm{~cm}$ x $20 \mathrm{~cm}$.

\section{Number of ear per hectare}

The number of ears of corn per hectare was influenced to a highly significant ( $p<0.01)$ both by the main effects of the NPS fertilization rate and by the row spacing (Table 4). The interaction effects of NPS fertilization rates and row spacing on the number of ears per hectare were also highly significant ( $p$ <0.01) (Table 6). The highest number of ears per hectare $(69,976)$ was measured when using $150 \mathrm{~kg}$ NPS ha ${ }^{-1}$ with a row spacing of $75 \mathrm{~cm}$, followed by an application of $200 \mathrm{~kg}$ NPS ha ${ }^{-1}$ with $75 \mathrm{~cm}$ row spacing $\left(69,317 \mathrm{ha}^{-1}\right)$.

Deviating from this, the lowest number of ears per hectare $(43,947)$ from the closest row spacing $(55 \mathrm{~cm})$ was measured with $0 \mathrm{~kg} \mathrm{NPS} \mathrm{ha-1} \mathrm{(Table} \mathrm{3).}$

Sulphurs facilitates N and P absorption, cell division, chlorophyll synthesis and photosynthesis Rao et al [76] and can thus significantly increase the ear per hectare. Similarly, Maral et al [78] reported that increasing the nitrogen content from 50 to $250 \mathrm{~kg} \mathrm{ha}^{-1}$ significantly increased the number of ears per plant from 1.2 to 2.05. Strong competition between plants for the incident photosynthetic photon flux, soil nutrients and soil water, which leads to a limited supply of carbon (C) and N, increases the sterility of maize Lemcoff and Lomis [80]. In agreement with the results of this study, Abuzer et al [63] reported that increasing plant density by reducing plant spacing significantly reduced the number of ears per hectare due to the decreased supply of nitrogen, photosynthesis and water to the growing ears. 
Table (3). Interaction effects of NPS fertilizer rates and inter- row spacing on number of ears per hectare of maize.

\begin{tabular}{lllll}
\hline NPS rate $\left(\mathrm{kg} \mathrm{ha}^{-1}\right)$ & \multicolumn{4}{c}{ Inter row spacing $(\mathrm{cm})$} \\
\cline { 2 - 5 } 0 & 55 & 65 & 75 & 85 \\
\cline { 2 - 5 } 50 & $43947^{\mathrm{b}}$ & $55651^{\text {bcde }}$ & $56797^{\text {cdef }}$ & $58766^{\text {defg }}$ \\
100 & $45755^{\mathrm{bc}}$ & $60760^{\text {defg }}$ & $66096^{\text {fgh }}$ & $65756^{\text {efgh }}$ \\
150 & $46256^{\mathrm{bc}}$ & $62626^{\text {defg }}$ & $68267^{\text {hh }}$ & $69240^{\mathrm{h}}$ \\
200 & $52087^{\mathrm{bcd}}$ & $63289^{\mathrm{a}}$ & $69976^{\mathrm{h}}$ & $69317^{\mathrm{h}}$ \\
\hline LSD (0.05) & $53714^{\mathrm{bcde}}$ & $65256^{\mathrm{efgh}}$ & $69000^{\mathrm{h}}$ & $69217^{\mathrm{h}}$ \\
CV (\%) & 12176 & & & \\
\hline
\end{tabular}

$* *=$ Significant at $1 \%$ probability levels; LSD = Least Significant Difference; $C V=$ Coefficient of Variation. Means in columns and rows followed by the same letters are not significantly different at $5 \%$ level of significance

\section{Ear length}

The main factors and the interaction effect of the mixed NPS fertilization rate and the row spacing were highly significant $(\mathrm{P}<0.01)$ on the ear length of the maize (Table 4). Accordingly, the highest ear length $(29.17 \mathrm{~cm})$ with the highest mixed NPS fertilizer amount $\left(150 \mathrm{~kg} \mathrm{ha}^{-1}\right)$ with an interaction of the row spacing of $75 \mathrm{~cm}$ and the shortest ear length $(17.00 \mathrm{~cm})$ with the interaction of the fertilizer without NPS and $55 \mathrm{~cm}$ narrowest row spacing (Table 4).

In agreement with this result, [74] found that the highest ear length $(21.20 \mathrm{~cm})$ from the interaction of the row spacing $75 \mathrm{~cm}$ with the highest nitrogen rate $\left(180 \mathrm{~kg} \mathrm{ha}^{-1}\right)$ while the lowest ear length $(16.73 \mathrm{~cm})$ was recorded from the interaction of the closest row spacing of $55 \mathrm{~cm}$ without nitrogen application.

The reason for the better ear development with optimal supply of NPS fertilizer with optimal plant density improves the photosynthetic activity of the plant through sufficient nitrogen and phosphorus supply Jena et al [81]. Nitrogen is also an essential requirement for ear growth. If the soil was supplied with sufficient amounts of $\mathrm{N}$ and $\mathrm{P}$ during the vegetation period, these are essential for optimal maize growth and lead to grain production Kogbe [82].

Sulfur is also involved in the conformations and activities of many enzymes and stimulates semen production Scherer [83]. Better ear growth was achieved with mineral fertilizers, which had an impact on the yield. Orkaido et al [84] also reported that the use of $\mathrm{N}$ in combination with $\mathrm{P}$ showed a consistent increase in ear length ranging from 5.8 to $30 \%$ over the control. Lakshmi et al [85] also showed that the application of $60 \mathrm{~kg} \mathrm{~S} \mathrm{ha}^{-1}$ recorded the highest cob length and 100 grain weight of maize.

In the case of row spacing, Zamir et al [86] reported that the cob length decreased when the plant population increased significantly. The results agreed with the findings of Gobeze et al [87], who found that an increase in plant density from 5 to 15 plants $\mathrm{m}^{-2}$ reduced the ear length of maize from 17.0 to $12.23 \mathrm{~cm}$. Similarly, the result agreed with the results of Donatus et al [88], who found that increasing the plant population from 57,142 to 100,000 plants ha $^{-1}$ reduced the ear length of maize from 18.39 to $15.64 \mathrm{~cm}$. 
Table (4). Interaction effects of NPS fertilizer rate and inter-row spacing on ear length $(\mathrm{cm})$ of maize.

\begin{tabular}{lllll}
\hline NPS rate $\left(\mathrm{kg} \mathrm{ha}^{-1}\right)$ & \multicolumn{3}{c}{ Inter row spacing $(\mathrm{cm})$} \\
\cline { 2 - 5 } 0 & 55 & 65 & 75 & 85 \\
\cline { 2 - 5 } 50 & $17.0^{\mathrm{a}}$ & $18.22^{\mathrm{b}}$ & $23.32^{\mathrm{de}}$ & $24.85^{\mathrm{gh}}$ \\
100 & $22.0^{\mathrm{c}}$ & $23.65^{\mathrm{d}}$ & $25.54^{\mathrm{gh}}$ & $27.17^{\mathrm{i}}$ \\
150 & $24.0^{\mathrm{cf}}$ & $24.63^{\mathrm{fg}}$ & $28.0^{\mathrm{i}}$ & $28.60^{\mathrm{j}}$ \\
200 & $25.0^{\mathrm{gh}}$ & $25.24^{\mathrm{gh}}$ & $29.17^{\mathrm{1}}$ & $28.71^{\mathrm{j}}$ \\
\hline LSD (0.05) 0.2134 & $27.0^{\mathrm{i}}$ & $28.0^{\mathrm{h}}$ & $28.50^{\mathrm{j}}$ & $28.40^{\mathrm{j}}$ \\
CV (\%) 5.9 & & & & \\
\hline
\end{tabular}

$* *=$ Significant at $1 \%$ probability levels; LSD = Least Significant Difference; CV= Coefficient of Variation. Means in columns and rows followed by the same letters are not significantly different at $5 \%$ level of Significance

\section{Number of kernel per ear}

The analysis of variance showed that the number of grains per ear was influenced highly significantly $(\mathrm{p}<0.01)$ by the NPS fertilization rate and significantly $(\mathrm{p}<0.05)$ by the row spacing and the interaction effect of the two factors. The highest number of kernels per ears (472.3) was recorded in response to NPS applied at the rate of $200 \mathrm{~kg} \mathrm{NPS} \mathrm{ha}^{-1}$ and it was statistically at par with $150 \mathrm{~kg} \mathrm{~N} \mathrm{ha}^{-1}$ which was (470.08) at all times of application (Table 5). In disparity, the lowest number of kernels per (413) recorded from control plots. Fertilizer application rates might be ascribed to good physiological activities of the crop to attract assimilates. Maize inherent capability of the endosperm to attract assimilates (kernel sink capacity) is one of the most important physiological factors of the grain yield of cereal crops and may be the main constraint to yield Jones and Wendit [89].

In the same way, Masood et al [58] found that number of kernels per ear was increased as and attempts to increased to a certain level. With increased NPS level up to $200 \mathrm{~kg}_{\text {NPS }} \mathrm{ha}^{-1}$ levels might be ascribed to better uptake of all the nutrients and increased translocation of photosynthetic products from source to sink and increased photosynthetic assimilate production and its partitioning that might have favorable impacts on kernels per ear of maize. In conformity with this result, Degefa [90] confirmed that the highest number of kernels per ears (539.7) was taken from $87 \mathrm{~kg} \mathrm{~N} \mathrm{ha}^{-1}$. In line with thus result Dinkinesh [56] reported that the highest number of kernels (43) produced from the highest rate of NPSB fertilizers (183 kg ha ${ }^{-1}$ NPSB) whereas the minimum number of kernels per spike (35) was produced at nil NPSB rate.

Larger distances between the rows in the number of kernels per ear, which leads to less competition between the plants for the growth resource, which is manifested in a high number of kernels per ear. Consistent with this finding, Eskandarneja et al [75] reported that a row spacing of $30 \mathrm{~cm}$ produced more grains per ear than this 20 $\mathrm{cm}$ plant spacing. Abuzar et al [63] observed that an increase in plant density decreased the number of grains Ears $^{-1}$.

\section{Thousand kernel weight}

Grain weight is an important component of the yield that is very helpful in estimating the grain yield. The analysis of variance showed that the thousand grain weight of maize was significantly $(p<0.01)$ influenced by the main effect of the NPS fertilizer rate and the row spacing and was significantly influenced by the combined effect of the two factors (Table 5). The highest thousand grain weight of $(398.7 \mathrm{~g}$ ) was measured from $150 \mathrm{~kg}$ NPS ha ${ }^{-1}$, but it was on par with the thousand grain weight of $(392.6 \mathrm{~g})$ obtained from $200 \mathrm{~kg}$ NPS ha ${ }^{-1}$. Inconsistency, the lowest thousand grain weight of (327.3 g) recorded from the parcel with no NPS fertilizer. A general increase in the NPS rate from $0 \mathrm{~kg} \mathrm{NPS} \mathrm{ha}^{-1}$ to $200 \mathrm{~kg} \mathrm{NPS} \mathrm{ha}^{-1}$ significantly increased the thousand grain weight (Table 5).

The higher grain weight for compound fertilizers could be attributed to a positive interaction of the nutrients in 
the compound fertilizers. This result is consistent with the results of Zhao et al. [91] and. Mekdad [47]. Seeds, tubers, roots and fruits) led to an increased grain weight. The final weight of the grains thus results from the speed with which the grains accumulate dry matter and the duration over which this occurs Housely et al [92]. Phosphorus, which is responsible for good root growth, had a direct effect on the thousand grain weight, since $\mathrm{P}$ in an amount of $0 \mathrm{~kg} \mathrm{ha}^{-1}$ (control plots) gave the lowest thousand grain weight [93]. The application of sulfur fertilizer is also possible for maize production and productivity by improving the soil quality for healthy crop production, which led to an increase in the thousand grain weight Zhao et al [91]. Kebede et al [94] also reported that the highest thousand grain weight $(391.35 \mathrm{~g})$ was achieved with an $\mathrm{N}$ content of $92 \mathrm{~kg} \mathrm{~N} \mathrm{ha}^{-1}$, followed by $69 \mathrm{~kg} \mathrm{~N} \mathrm{ha}^{-1}$ (362.53 g). Largest row spacing of $75 \mathrm{~cm}$ the result is the highest thousand grain weight of $(389.4 \mathrm{~g})$ and the lowest thousand grain weight $(315.1 \mathrm{~g})$ measured at $55 \mathrm{~cm}$ row spacing (Table 5).

The decrease in weight of 1000 seeds could be attributed to the decrease in assimilate division among seeds as a result of increased competition between plants in utilizing environmental inputs in building a large amount of metabolites for use in developing new tissues, thereby reducing weight. In the case of plants with larger row spacing, however, due to the availability of more resources (light, nutrients, water) for a comparatively smaller number of plants that they used efficiently to produce larger grains. The result agreed with Ogunlela et al [95], Arif et al [96] and Mukhtar [97] who reported that the weight of 1000 grains decreased with increasing plant density.

Table (5). Main Effects of NPS fertilizer rates and Inter row spacing on thousand kernel weight, numbers of kernel per ear, stand count at harvest.

\begin{tabular}{llll}
\hline NPS rates $\left(\mathrm{kg} \mathrm{ha}^{-1}\right)$ & $\begin{array}{l}\text { Thousand kernel } \\
\text { weight. }\end{array}$ & $\begin{array}{l}\text { Number of kernel } \\
\text { per ears. }\end{array}$ & $\begin{array}{l}\text { Stand count percent at } \\
\text { harvest }\end{array}$ \\
\hline 0 & $327.3^{\mathrm{d}}$ & $413.4^{\mathrm{d}}$ & $0.9288^{\mathrm{d}}$ \\
50 & $352.6^{\mathrm{c}}$ & $444.6^{\mathrm{c}}$ & $0.9425^{\mathrm{c}}$ \\
100 & $354.2^{\mathrm{c}}$ & $458.7^{\mathrm{b}}$ & $0.9513^{\mathrm{cb}}$ \\
150 & $398.7^{\mathrm{b}}$ & $470.8^{\mathrm{a}}$ & $0.9545^{\mathrm{b}}$ \\
200 & $392.6^{\mathrm{a}}$ & $472.3^{\mathrm{a}}$ & $0.9657^{\mathrm{a}}$ \\
LSD (0.05) & 10.19 & 4.523 & 0.003792 \\
\hline Inter row spacing $(\mathrm{cm})$ & & & \\
& & & \\
55 & $315.1^{\mathrm{d}}$ & $398.2^{\mathrm{d}}$ & $0.896^{\mathrm{d}}$ \\
65 & $366.9^{\mathrm{c}}$ & $447.1^{\mathrm{c}}$ & $0.9437^{\mathrm{c}}$ \\
75 & $389.0^{\mathrm{b}}$ & $461.0^{\mathrm{b}}$ & $0.9583^{\mathrm{b}}$ \\
85 & $379.4^{\mathrm{a}}$ & $467.6^{\mathrm{a}}$ & $0.9637^{\mathrm{a}}$ \\
\hline LSD $(\mathbf{0 . 0 5})$ & 9.11 & 4.045 & 0.003792 \\
CV $(\boldsymbol{\%})$ & 3.4 & 7.2 & 3.4 \\
\hline
\end{tabular}

LSD=least significant differences CV=Coefficient Variation Means of the same letters does not show significant different.

\section{Above ground dry biomass}

The main effects of NPS content and row spacing and their combination effects had a highly significant ( $p$ $<0.01)$ influence on the dry aboveground biomass. The highest above-ground dry biomass yield $\left(20,667 \mathrm{~kg} \mathrm{ha}^{-1}\right)$ was measured with the combination of the highest NPS fertilizer amount $200 \mathrm{~kg} \mathrm{ha}^{-1}$ and $55 \mathrm{~cm}$ row spacing followed by $200 \mathrm{~kg}$ NPS ha- ${ }^{-1}$ at $65 \mathrm{~cm}$ spacing $\left(23,447 \mathrm{~kg} \mathrm{ha}^{-1}\right)$ during the lowest above-ground dry biomass $\left(12,340 \mathrm{~kg} \mathrm{ha}^{-1}\right)$ was measured at $55 \mathrm{~cm}$ row spacing without NPS fertilization. Thus, an increase in the biomass yield could be due to the general improvement in the vegetative growth of the plant through the application of NPS fertilizer in combination with close spacing, vegetative growth of the plants with higher $\mathrm{N}$ and $\mathrm{S}$ availability and $\mathrm{P}$ also plays a decisive role in the early root spreading which could increase the plant's nutrient uptake, consequently leading to increased vegetative growth and an increase in NPS demand with biomass yield, which is improved by decreased row spacing and greater plant density Jordan et al [98]. 
Dinkinesh [56] also reported that the highest above-ground dry biomass (11772 $\left.\mathrm{kg} \mathrm{ha}^{-1}\right)$ was obtained when applying the highest rate (183 $\left.\mathrm{kg} \mathrm{ha}^{-1} \mathrm{NPSB}\right)$, while the lowest above-ground dry biomass (3756 kg ha-1) was obtained when using control treatment produced. Ayman and [99] also reported on the maximum above-ground dry biomass of $28,914 \mathrm{~kg} \mathrm{ha}^{-1}$ in maize in response to the $\mathrm{N}$ application of $330 \mathrm{~kg} \mathrm{ha}^{-1}$ and a maximum of 57,124 plants ha ${ }^{-1}$. The increase in the biomass yield with an increase in the nitrogen rate is expected, since nitrogen is known to promote vegetative growth Tisdale et al [100]. Increasing the row spacing from $55 \mathrm{~cm}$ to $85 \mathrm{~cm}$ decreased the dry biomass yield above ground and showed a constant decrease. This could be due to a higher plant population recorded with close spacing between and within rows and thus higher dry matter production. Consistent with this finding, Mahmood et al [101] showed that the total biomass yields of maize in the narrow row spacing $(20 \mathrm{~cm})$ were significantly higher than in the wider row spacing $(30 \mathrm{~cm})$ due to the higher number of taller plants per unit area and the better interception of solar radiation.

\section{Harvest index (HI)}

The harvest index indicates the physiological efficiency and ability of a culture to convert total dry matter into an economic yield. The analysis of variance showed that the harvest index was highly significantly $(p<0.01)$ influenced by the main effect of the NPS rate and significantly $(\mathrm{p}<0.05)$ by the main effect of the row spacing. While the interaction of two factors is not significant. With the increase in the NPS application rate from 0 to $200 \mathrm{~kg}$ NPS ha ${ }^{-1}$, the harvest index increased and began to decrease above this rate. The highest harvest index (30.4\%) was recorded for treatments with $200 \mathrm{~kg}$ NPS ha ${ }^{-1}$. However, it is statistically on par with the harvest index $(29.38 \%)$ recorded from a treatment with $150 \mathrm{~kg} \mathrm{NPS} \mathrm{ha}^{-1}$, while the lowest harvest index $(24.3 \%)$ was obtained from treatments that were under control and $55 \mathrm{~cm}$ Spaced.

The result agreed with that of Addis and Hae Ko Kim [102] who reported that increasing the N from 0 to $75 \mathrm{~kg}$ $\mathrm{N} \mathrm{ha}^{-1}$ increased the harvest index from $49.493 \%$ to $54.620 \%$, but the harvest index was increased from a higher dose of treatment from $100 \mathrm{~kg} \mathrm{~N} \mathrm{ha}^{-1}$ to $125 \mathrm{~kg} \mathrm{~N} \mathrm{ha}^{-1}$ reduced from $50.817 \%$ to $47.663 \%$ or in accordance with this, Abdo [103] reported the highest harvest index (30.61\%) from treatments with the lowest nitrogen application rate of $23 \mathrm{~kg} \mathrm{~N} \mathrm{ha}^{-1}$. The highest harvest index $(30.6 \%)$ was recorded at the widest distance $(85 \mathrm{~cm})$, while the lowest $(23 \%)$ was due to the narrowest $(55 \mathrm{~cm})$ distance. The harvest index increased with increasing distance between the rows (Table 8). The maize harvest index typically decreases when the plant densities are above optimal, as the intra specific competition reduces the distribution of the biomass on the ears Pagano et al [104].

\section{Agronomic efficiency}

The agronomic efficiency was influenced to a highly significant $(\mathrm{p}<0.01)$ by the main effect of the NPS fertilizer rates and the row spacing. As the NPS application rate increased from 0 to $1500 \mathrm{~kg} \mathrm{NPS} \mathrm{ha}^{-1}$, the agronomic efficiency was increased; however, increasing the NPS rate from 150 to $200 \mathrm{~kg} \mathrm{NPS} \mathrm{ha}^{-1}$ did not significantly increase the agronomic efficiency, but decreased the agronomic efficiency.

This could be due to the fact that the input-output relationship, which follows the law of decreasing yield between fertilizer and yield, and also the reaction of the varieties to the supplied nutrients due to their genetic makeup was different.[105] also reported that the agronomic efficiency of wheat decreases with increasing $\mathrm{N}$ contents. Buah and Mwinkara [106] reported that when assessing the agronomic responsiveness of 13 sorghum genotypes, which differed in nitrogen use efficiency at three $\mathrm{N}$ rates $\left(0,50\right.$ and $\left.100 \mathrm{~kg} \mathrm{~N} \mathrm{ha}{ }^{-1}\right)$, and in the sorghum types with high nitrogen use efficiency higher yields were observed than in the low nitrogen consumption types.

\section{Grain Yield}

The analysis of variance showed that the main factors and the interaction effect of the mixed NPS fertilizer amounts and the row spacing were highly significant $(\mathrm{P}<0.01)$. Accordingly, the highest grain yield $(6577 \mathrm{Kg}$ $\mathrm{ha}^{-1}$ ) was recorded at the mixture of the highest blended NPS fertilizer rate $\left(150 \mathrm{~kg} \mathrm{ha}^{-1}\right)$ and the row spacing of $75 \mathrm{~cm}$, while the lowest grain yield $\left(2850 \mathrm{~kg} \mathrm{ha}^{-1}\right)$ was recorded at the blend of the narrowest inter-row spacing of $55 \mathrm{~cm}$ with control plot (Table 6). It is clear from the result that grain yield increased in response to an optimal NPS fertilization rate, possibly due to a higher leaf area index (LAI), plant height, number of kernels per ear, 1000 kernel weight, and number of cobs per plant. The $\mathrm{N}$ has synergistic effects on growth and yield 
attributes, which leads to a stronger translocation of photosynthesis from the source to the sink, a positive effect on the physiological process, plant metabolism, growth and it is the main component of proteins, enzymes, amino acids, Amides and nucleic acids Yayock [107] and leads there to a higher grain yield. Similarly, Hamid and Nasab [50] suggested that $\mathrm{N}$ application had a much greater impact on corn grain yield; this could be due to the fact that the application of $\mathrm{N}$ fertilizers to plants increases the uptake of other nutrients. The $\mathrm{P}$ supply is especially important for stimulating early root formation and growth, functions in plant molecular structure as a element of nucleic acid and phospholipids, with crucial roles in energy metabolism participation in signal transduction pathways phosphorylation and controlling key enzyme reactions Marschner[108]. Phosphorus also significantly enhances the number of cobs per plot, 1000-grain weight, and grain yield over the control Qasim et al [109]. Similarly, Olusegun[110] reported that use of the mixture of $\mathrm{N}$ at $90 \mathrm{~kg} \mathrm{~h}^{-1}$ and $\mathrm{P}$ at $30 \mathrm{~kg} \mathrm{~h}^{-1}$ gave the highest grain yield of maize.

Sulphur also encourages photosynthetic activity by increasing chlorophyll pigments, synthesis of essential amino acids and proteins, translocation and utilization of starch and nitrogen and all these functions finally converge to increase maize yield Gahlout et al [112]. The combined use of Phosphorus with nitrogen increased the yield significantly Moschler and Martens [113].

The low yield in unfertilized plots might have been owing to reduced leaf area development resulting in lesser radiation interception and, consequently, low efficiency in the conversion of solar radiation Sallah et al [114]. The highest grain yield per hectare with a larger row spacing $(75 \mathrm{~cm})$ and optimal nutrient use efficiency could be due to the high number of ears per plant and the large leaf area, as more growth factors and better light penetration at the largest row spacing.

This could be due to the high plant population, which goes beyond the optimum and leads to intense competition between the plants for the incident photosynthetic photon flux density, soil nutrients and soil water. Huseyin and Omar [115] also reported that the grain yield of maize increased significantly with increasing plant density and nitrogen fertilization, up to 88,000 plants per hectare and $240 \mathrm{~kg}$ nitrogen ha- 1 in popcorn. Similar to the authors mentioned above, Cassman et al[116] reported that greater synchronicity between plant demand and nutrient supply is necessary to improve nutrient use efficiency, and that a shared $\mathrm{N}$ application during the growing season rather than a single, larger application is known to be effective in increasing $\mathrm{N}$ use efficiency raise.

Table (6). Interaction effect of both NPS fertilizer rate and inter row spacing on grain yield.

\begin{tabular}{lllll}
\hline NPS fertilizer & \multicolumn{4}{c}{ Inter row spacing $(\mathrm{cm})$} \\
\cline { 2 - 5 } rates $\left(\mathrm{kg} \mathrm{ha}^{-1}\right)$ & 55 & 65 & 75 & 85 \\
\cline { 2 - 5 } 0 & $2850.00^{\mathrm{a}}$ & $3765.0^{\mathrm{b}}$ & $3869.2^{\mathrm{c}}$ & $3964.7^{\mathrm{d}}$ \\
50 & $3883.0^{\mathrm{c}}$ & $3973.5^{\mathrm{d}}$ & $4200.0^{\mathrm{g}}$ & $4136.6^{\mathrm{ef}}$ \\
100 & $4095.2^{\mathrm{e}}$ & $4180.8^{\mathrm{fg}}$ & $4478.0^{\mathrm{j}}$ & $5028.2^{\mathrm{mm}}$ \\
150 & $4282.7^{\mathrm{h}}$ & $4577.7^{\mathrm{k}}$ & $6577^{\mathrm{m}}$ & $6227.8^{\mathrm{m}}$ \\
200 & $4415.8^{\mathrm{i}}$ & $4719.8 .0^{\mathrm{l}}$ & $6200^{\mathrm{m}}$ & $6120^{\mathrm{m}}$ \\
\hline LSD(0.05) & 229.1 & & & \\
\hline CV(\%) & 3.9 & & & \\
\hline
\end{tabular}

LSD=Least significance Differences CV=Coefficient of Variations, means in the tables indicates the same letters does not show significance differences.

\section{Partial Budget Analysis}

The partial economic analysis was performed using the methodology described in the methodology of CIMMYT [41]. From the final trial data, the gross yield for 20 treatments was determined and the recommended value of $10 \%$ of all treatments or the unadjusted grain yield (UGY) was reduced to obtain an adjusted grain yield. The net benefit was calculated by subtracting the total variable costs (TVC) from the gross field benefit (GFB) for each treatment. The costs and benefits were calculated for each treatment. All variable costs were calculated without the price of other agronomic practices such as weeding, farm protection and harvesting as they were consistent for all treatments. The cost of NPS fertilizer was ETB $18 \mathrm{~kg}^{-1}$, urea was ETB $16 \mathrm{~kg} \mathrm{ha}^{-1}$ variety Melkassa-II seed 
was ETB $65 \mathrm{~kg}^{-1}$. The partial budget analysis showed that the highest net benefit of $91608 \mathrm{ETB} \mathrm{Birr} \mathrm{ha}^{-1}$ was achieved in the treatment that received $150 \mathrm{~kg}$ NPS ha-1 and $75 \mathrm{~cm}$ row spacing, while the lowest net benefit of Birr 44010 ETB ha ${ }^{-1}$ from the combination without NPS and $55 \mathrm{~cm}$ row spacing. For farmers to consider treatment advisable, a marginal return on investment (MRR) between 50\% and 100\% was the minimum acceptable return CIMMYT

\section{Conclusions}

The low yield of maize production due to poor agronomic practices such as poor soil fertility and plant density requires special attention. Therefore, the present experiment was carried out in the main growing season 2019/2020 at Haramaya University, Eastern Hararghe Zone, Oromia Regional State, with the aim of determining the effect of mixed NPS fertilizer amounts and row spacing on the yield components and the corn yield and to evaluate the Cost-benefit analysis of mixed NPS fertilizers in the yield of corn at the Haramaya Research site. Factorial combinations of five levels of the NPS rate $\left(0 \mathrm{~kg} \mathrm{ha}^{-1}, 50 \mathrm{~kg} \mathrm{ha}^{-1}, 100 \mathrm{~kg} \mathrm{ha}^{-1}, 150 \mathrm{~kg} \mathrm{ha}^{-1}\right.$ and $200 \mathrm{~kg}$ $\mathrm{ha}^{-1}$ ) and four row spacing $(55 \mathrm{~cm}, 65 \mathrm{~cm}, 75 \mathrm{~cm}$ and $85 \mathrm{~cm}$ ) were laid out in a randomized complete block design with three repetitions using the maize variety Melkassa 2.

The main effects of the NPS fertilization rate were shown to be highly significant $(\mathrm{P}<0.01)$ per day with $50 \%$ anthesis, 50\% silk formation, $90 \%$ physiological maturity, leaf area, leaf area index, number of grains per ear, surface dry biomass, grain yield, agronomic efficiency, Stock counting at harvest. Highest day up to 50\% anthesis (82 days), 50\% silk formation (86 days), physiological maturity (128 days), highest leaf area (8620 $\mathrm{cm}^{2}$ ), leaf area index (4.15), number of grains per ear (472.3) and above-ground dry biomass $\left(20667 \mathrm{~kg} \mathrm{~h}^{-1}\right)$ were recorded from 200 NPS fertilization rates, while the lowest leaf area (6785.5), leaf area index (3.6), number of grains per ear (413.3) and above-ground dry biomass (12340 kg ha-1) were recorded from $55 \mathrm{~cm}$ without NPS. The NPS fertilizer rates also had a significant $(\mathrm{P}<0.05)$ effect on the harvest index and thousand grain weight. Significantly, the highest harvest index (30.4\%) of 200 NPS kg ha ${ }^{-1}$ and the highest thousand grain weight (398.7 g) of $150 \mathrm{NPS} \mathrm{kg} \mathrm{ha-1}$ were measured.

The main effect of the row spacing showed highly significant $(\mathrm{P}<0.01)$ effects on $50 \%$ anthesis, 50\% silk formation, leaf area, leaf area index, population count and harvest index. Among the row spacing, the highest $50 \%$ anthesis (81 days), 50\% silk formation (84 days), leaf area $\left(8463 \mathrm{~cm}^{2}\right)$, stand number $(96.32 \%)$ and harvest index $(30.4 \%)$ were observed at the widest row spacing $(85 \mathrm{~cm})$, while the highest aboveground dry biomass $\left(20,667 \mathrm{~kg} \mathrm{ha}^{-1}\right)$ and the highest leaf area index $(4,617)$ were measured with the narrowest row spacing $(55 \mathrm{~cm})$ and also significant row spacing $(\mathrm{P}<0.05$.) influence on physiological maturity and number the grains per ear, grain yield, thousand grain weight, the highest grain yield is measured at $75 \mathrm{~cm}$ row spacing.

The interactions of the NPS fertilizer quantities with the row spacing showed a highly significant $(\mathrm{P}<0.01)$ effect on the aboveground dry biomass, ear length, number of ears per hectare, plant height, agronomic efficiency, grain yield, but a significant effect $(\mathrm{P}<0.05)$ on number of ears per plant, number of grains per ear. The highest plant $(246 \mathrm{~cm})$ was recorded from $200 \mathrm{NPS} \mathrm{kg} \mathrm{ha-1}$ with $(55 \mathrm{~cm})$ row spacing, the highest number of ears per plant $(1,467)$, the highest ear length $(29 \mathrm{~cm})$, the highest number of ears per hectare $(69,999)$, highest Grain yield per hectare (6577 kg ha-1), agronomic efficiency (30.65) were measured from $150 \mathrm{NPS} \mathrm{kg} \mathrm{ha}{ }^{-1}$ at 75 cm row spacing.

The highest economic benefit $\left(91,608 \mathrm{ETB} \mathrm{ha}^{-1}\right)$ and the higher acceptable MRR $(1745 \%)$ were obtained from a combination of $150 \mathrm{~kg}$ NPS ha $^{-1}$ and a row spacing of $75 \mathrm{~cm}$, while the lowest economic benefit (40,010 ETB ha ${ }^{1}$ ) was. was a combination of control and $55 \mathrm{~cm}$ row spacing. From the results of the study it can therefore be concluded that the application of $150 \mathrm{~kg}$ NPS ha-1 and $75 \mathrm{~cm}$ row spacing was suitable to increase the productivity of the maize variety Melkassa-II in the study area during the main cultivation. However, since this result is valid for one season and one location;

Acknowledgement: It is my great pleasure to meet my key advisor, Dr. Jemal Abdulahi, to extend my sincere appreciation and special thanks for his valuable advice, sustained and educated guidance, enthusiastic collaboration and critical review of the research proposal and the manuscript of the dissertation. Their constructive comments and their professional commitment contributed immensely to the success of the research work and the writing of this article review. 


\section{References}

[1] FAO.," Food and agriculture data, Italy, Rome", Online. FAO. Retrieved October 14, 2019.

[2] AGR, Focus on staple on crop,"Nairobi, Kenya., 2013.

[3] Christian R., Angelika C., Christoph GJ., Frank T., Albrecht EM, " Genomic and metabolic prediction of complex heterotic traits in hybrid maize" Nat. Genet., vol. 44, PP.217-220, 2012

[4] Shiferaw, B., Prasanna, B., Hellin, J. and Banziger, M. "Feeding a Hungry World: Past Successes and Future Challenges to Global Food Security in Maize". Food Security, vol.3, pp.307-327, 2011.

[5] Fageria, N.K. and Baligar V. C., "Enhancing nitrogen use efficiency in crop plants", 2005.

[6] Endris, S and Dawid, J.,"Yield response of maize to integrated soil fertility management on acidic nitosol of Southwestern Ethiopia". Journal of Agronomy, vol.14(3), pp.152-157. 2005.

[7] Fufa, B., Behute, B., Simons, R., and Berhe, T., "Strengthening the teff value chain in Ethiopia (Unpublished Report)". pp. 12. Agricultural Transformation Agency. 2011.

[8] Cisse, L., \& Amar, B.," The importance of Phosphate fertilizer for increased crop production in developing countries. In Proceedings of the AFA 6th international annual conference Helon 31 January -2 February". Advances in Agronomy, vol.88 pp. 97-185. 2000.

[9] Chimdessa, D., "Blended fertilizers effects on maize yield and yield components of Western Oromia, Ethiopia". Agriculture, Forestry and Fisheries, vol.5(5), pp.151-162. 2006.

[10] Buah J., and Mwinkaara S., " Response of Sorghum to Nitrogen fertilizer and Plant density in the Guinea savanna Zone", Journal of Agronomy, vol. 8 (4); pp.124-130. 2009.

[11] Torbert, H.A., K.N. Potter and J.E. Morrison,."Tillage system, fertilizer nitrogen rate and timing effect on corn yields in the Texas Black land prairie", Agronomy Journal, vol. 93, pp.1119-1124. 2001.

[12] Samira M., A. Hussein, M.A. Haikel and M.A. El-Masry, "Effect of some preceding crops, hill spacing and nitrogen fertilization on yield attributes and grain yield of maize under reclaimed sandy soil conditions in East Delta. Proc. 8th Conf". Agron., Suez Canal Univ., Ismailia, Egypt, 28-29 Nov. pp. 174-18. 1998.

[13] Hefny M, Aly AA., "Yielding Ability and Nitrogen Use Efficiency in Maize Inbred-lines. 2008.

[14] Onasanya RO, Aiyelari OP, Onasanya A, Nwilene FE, Oyelakin O., "Effect of Different Levels of Nitrogen and Phosphorous Fertilizers on the Growth and Yield of Maize (Zea mays L.) in Southwest Nigeria", International Journal Agriculture Research, vol.4.(6), pp.193-203. 2009.

[15] Bellete, T., " Fertility mapping of soils of Abay-Chomen District, Western Oromia, Ethiopia ". MSc.Thesis. Haramaya University, Haramaya, Ethiopia.2014.

[16] Zeleke, G., Agegnehu, G., Abera, D., \& Rashid, S., "Fertilizer and soil fertility potential in Ethiopia: Constraints and opportunities for enhancing the sys-tem", IFPRI., 2010.

[17] Chen ML, Jiang XL, Zoov BY, Zheri ZY." Mathematical models and best combination of high yield cultivation technique for rapeseed variety Zhenyouyoum". Acta Agric Zhejiian genesis vol.6, pp.22-26, 1994.

[18] Adepetu, J.A., "Phosphorus fertilization of tropical crops. In: Enzman. Mutscher and Franke (Eds). Nutrients Supply to Tropical Crops", Institute of Trop. Agric, Leipzig Publ., pp. 21-288, 1993.

[19] Tandon, H.L.S. "Sulfur Fertilizer for Indian Agriculture. A Guide Book", Fertilizer Development and Consultation Organization (C-110 Greater Kailash-1, New Delhi, 1998.

[20] Sangoi, L., "Understanding plant density effects on maize growth and development: an important issue to maximize grain yield". Ciência Rural, Santa Maria, vol.31(1), pp.159-168, 2000.

[21] Casal, J.J., V.A. Deregibus and R.A. Sanchez.," Variations in tiller dynamics and morphology in Lolium multiflorum Lam. vegetative and reproductive plants as affected by differences in red/far-red irradiation". Annals of Botany, London, vol.56, pp.533-559. 1985.

[22] Gardner, F.P., R.B. Pearce and R.L. Mitchell.," Physiology of crop plants". Ames: Iowa State University, pp.327, 1985.

[23] Anjum, J. I, C. N. Ali, F. H. Sahi, Z. H. Khan, and M. Jafar.,"Effect of plant population and fertilizer application on growth and yield of summer maize". Journal of Agricultural Research Lahore.vol. 30(4) pp.453-457. Anonymous (2000) "Fertilizers and their use", FAO, International Industry Association, Rome, 1992.

[24] Sabir, M., R Iqbal, M.A Malik and A. Hussain., "Effect of size of nutritional area on the growth and yield of maize (Zea mays L.). grown at different fertility levels", Journal of Science. vol. 30(3), pp. 211-214, 1987.

[25] Mahmood, M.T., M. Maqsood, T. H. Awan and R. Sarwa, " Effect of different levels of nitrogen and intra 
row plant spacing on yield and yield components of maize", Journal of agricultural science, vol.38(2) pp. 35-38, 2001.

[26] Sangoi, L. and R.J. Salvador." Influence of plant height and leaf number on maize production at high plant densities", 1998.

[27] Haramaya agriculture and natural resource office, Haramaya, Ethiopia, 2019.

[28] Haramaya University Meteorological Observatory, Haramaya, Ethiopia, 2019.

[29] Tekalign Tsegaw and Hammes, P. S., "Growth and productivity of potato as influenced by cultivar and reproductive growth, I. Stomatal conductance, rate of transpiration, net photosynthesis, and dry matter production and allocation. pp. 15. In: Tobiyaw Yidenekal, Yared Mammo and Tadele Tefera (eds.)" Journal Reprints in Horticulture Research and Extension Office, Alemaya University, 2005.

[30] Munson, R.D. and Nelson, W.L., "Principles and practices in plant analysis; Soil Testing and Plant Analysis". Soil Science Society of America, vol. 40 pp. 223-248, 1993.

[31] Kjeldahi. "The total nitrogen in the soil was determined by the Kjeldahl method".

[32] Olsen, S.R., Cole, C.V., Watenabe, F.S. and Dean, L.A., "Estimation of the valuable phosphorus in soil by extraction with sodium bicarbonate" United States Department of Agriculture Circ., 939.USA, 1995.

[33] Walkley, A. and Black, C.A., "An examination of different methods for determining soil organic matter and proposed modification by chronic acid titration method", Soil Science, vol. 37, pp. 29-38. 1934

[34] Chesnin, L. and Yien, C.H., "Turbidi metric determination of available sulfates", Soil Science Society of America Journal, vol. 15, pp. 149-151, 1951.

[35] Moodie, C., Smith, D., and Mc Creerry, R., "Laboratory manual for soil fertility", 1954.

[36] Cottenie, A., "Soil and plant testing as a basis of fertilizer recommendations", FAO soil bulletin 38/2. Food and Agriculture Organization of the United Nations, Rome, 1980.

[37] MoARD (Ministry of Agriculture and Rural Development), "Directory of Released Crop Varieties", Addis Ababa, Ethiopia. Model for Policy Analysis of Agricultural Commodities and Trade (IMPACT): Model Description. International Food Policy Research Institute: Washington, D.C. 2009.

[38] Francis, C.A., Rutger, J.N., and palmer A.F.E., "Rapid method for plant leaf area estimation in maize (Zea mays L.)", journal of Crop Science. vol. 9, pp. 537-539, 1969.

[39] Diwaker, B. and Oswalt, D. L., "Research Planning and Data Handling". ICRSAT. Andhra Pradesh, India.pp. 89, 1992.

[40] Craswell, E.T. and Godwin, D.C., In: Mangle, K. and Kirkby, E.A.," Principles of Plant Nutrition". Panima Publishing Corporation. New Delhi, India, 1984.

[41] CIMMYT (International Maize and Wheat Improvement center). "Farm Agronomic to farmer"s recommendation", An Economic Training Manual. Completely revised edition, D.F. Mexico. 51p. 1988.

[42] GenStat," GenStat Procedure Library Release., 16th edition", VSN International Ltd., 2013.

[43] Bouyoucos, G.J., "Hydrometer Method improved for making particle size Analyses of soils", Agronomy Journal, vol. 54(5) pp. 464-465, 1962.

[44] Landon, J.R. " Booker Tropical Soil Manua", A hand book for soil survey and Agricultural Land Evaluation in the Tropics and Subtropics. Longman Scientific and Technical, Essex, New York. 474p, 1991.

[45] Murphy, B. W., " Soils their properties and management. "3rd edn. (Oxford University Press: Melbourne)", 2007.

[46] EthioSIS (Ethiopian Soil Information System)," Soil analysis report. Agricultural Transformation Agency", 2013.

[47] Mekdad, A.A.," Sugar beet productivity as affected by nitrogen fertilizer and foliar spraying with boron", International Journal of Current Microbiology and Applied Science, vol. (4), pp. 181-196, 2015.

[48] Moges Asefa," Effect of nitrogen fertilizer and plant densities on yield and yield related traits of Maize (Zea mays L.) under irrigation in southern Tigray, Ethiopia. MSc Thesis, Haramaya University, Haramaya, Ethiopia., 2015.

[49] Abdulatif Ahimed, 2002. Effect of Plant Population Density and N Fertilizer Rate on Maize (Zea mays L.) intercropped in the Alleys of Chat (Catha edulis Forskk) culture at Tinike, Eastern Hararghe. MSc Thesis presented on to School of Graduate Studies of Haramaya University, Haramaya, Ethiopia., 2002.

[50] Hamid, A., and Nasab A.D.M.., "The effect of various plant densities and N levels on phonology of two medium maturity corn hybrids". Iranian Journal of Agricultural Sciences, vol.32, pp. 857-874, 2001.

[51] Wakjira Hundessa, " Effect of Blended NPS Fertilizer Application and Inter Row Spacing on Green Cob, Yield, Yield Components and Growth of Maize (Zea mays L.) Under Supplementary Irrigation at Guliso, 
Western Ethiopia ". MSc thesis, Haramaya University Haramaya, Ethiopia, 2008.

[52] Imran, S., Arif, M., Khan, A. Shah, W., Abdul, L., Ali Khan, M." Effect of nitrogen level and plant population on yield and yield components of maize". Advanced crop technology, India journal, Vol. 3, pp. $1-71,2015$.

[53] Akbar, H., Miftahullah Jan., Jan M.T and Ihsanullah, 2002. Yield potential of sweet corn as influenced by different levels of nitrogen and plant population. Asian Journal of Plant Science, vol. 6, pp. 631-633. 2002.

[54] Sanchez, P.A., K.D. Shepherd, M.J. Soul, F.M. Place, R.J. Buresh and A.M.N. Zac.". Soil fertility replenishment in Africa. Replenishing soil fertility Africa, SSSA", Special Publication vol. 51. SSSA, Madison, USA. 1997.

[55] Alemayo Tesfaye, "Effect of Blended NPS Fertilizer Application and Inter Row Spacing on Green Cob, Yield, Yield Components and Growth of Maize (Zea mays L.) Under Supplementary Irrigation at Guliso, Western Ethiopia ", (MSc thesis, Haramaya University, Haramaya, Ethiopia), 2018.

[56] Dinkinesh., "Effects of Blended Fertilizer (NPSB) Rates on Yield, Yield Components and Grain Quality of Durum Wheat Triticum turgidum L. Var. Durum Varieties in Minijar Shenkora District, Central Ethiopia " MSc thesis, Haramaya University, Haramaya, Ethiopia, 2018.

[57] Jeet, S., Singh, J. P., Kumar, R., Prasad, R. K., Kumar, P., Kumari, A., \& Prakash, P., " Effect of nitrogen and sulphur levels on yield, economics and quality of QPM hybrids under dry land condition of eastern Uttarpradesh, India". Indian Journal of Agricultural Sciences, vol. 4(9), pp. 31-38, 2012.

[58] Masood, T.A.R.I.Q., Gul, R.O.Z.I.N.A., Munsif, F.A.Z.A.L., Jalal, F.A.Z.A.L., Hussain, Z.A.H.I.D.,

[59] Gutierrez Boem, F.H. and. Thomass G.W., "Phosphorus nutrition affects wheat response to water deficit". Agronomy Journal, vol. 90, pp.166-171, 1998.

[60] Sakal, R., Sinha, R.B., Singh, A.P., Bhogal, N.S. and Ismail, M.D." Influence of sulfur on yield and mineral nutrition of crops in maize-wheat sequence". Journal of Indian Social Soil Science, vol. 48, pp. 325-329. 2000.

[61] Lakew Getaneh, Ketema B., and Tamado T.,"Growth and Productivity of Maize (Zea mays L.) as Influenced by Inter- and Intra-Row Spacing”, Journal of Biology, Agriculture and Healthcare, Vol. 6, pp.13, 2016.

[62] Sangoi, L. and R.J. Salvador., " Influence of plant height and leaf number on maize production at high plant densities", 1998.

[63] Abuzar, M.R., Sadozai. G.U., Baloch, M.S., Baloch, A.A., Sha, I.H., Javaid, T. and Hussain," Effect of plant population densities on yield of maize", Journal of Animal and plant sciences, vol. 21(4), pp. 692695. 2011.

[64] Shamim, G., Khan, M. H., Khanday, B. A., \& Nabi, S., " Effect of sowing methods and NPK levels on growth and yield of rain fed maize (Zea mays L.) " Vol. 2015). Hindawi Publishing Corporation, 2015.

[65]. Workayehu, T., "Effect of nitrogen fertilizer rates and plant densities on grain yield of maize". African Journal of Crop Science vol. 8(3), pp 273-282, 2000.

[66] Melesse H.," Response of bread wheat (Triticum aestivum L.) varieties to $\mathrm{N}$ and P fertilizer rates in Ofla district, Southern Tigray, Ethiopia", African Journal of Agricultural Research, vol. 12 (19), pp. 1646-1660, 2017.

[67] Tilahun Abera and Tamado Tana. "Growth, yield component and yield response of durum wheat (Triticum turgidum L. Var. Durum) to blended NPS fertilizer supplemented with N rates at Arsi Negelle, Central Ethiopia". African Journal of Plant Science vol. 13(1), pp. 9-20, 2018.

[68] Tenaw Workayehu.," Effect of nitrogen fertilizer rates and plant densities on grain yield of maize". African journal of Crop Science, vol. 8, pp. 273-282, 2000.

[69] Habtamu Admas Desta, "Response of maize (Zea mays L.) to different levels of nitrogen and sulfur fertilizers in Chilga District, Amhara National Regional State, Ethiopia". Basic Research Journal of Soil and Environmental Science, vol. 3(3), pp. 38-49, 2015.

[70] Singh N.P., and R.A. Singh, " Scientific crop production, X press Graphics, Delhi-28", 1st ed., India 2002.

[71] Goldsworthy, P. R. and Taylor, R. S., "The effect of plant spacing on grain yield of tall and short sorghum in Nigeria". Journal of Agricultural Science, vol. 50 (8), pp. 566-568, 1990.

[72] Matthews, E., Ibeawuchi I.I., Miriam O., Chinyere P., and Onyia V.N.,"Plant spacing, dry matter accumulation and yield of local and improved maize cultivars". Journal of American Science, vol. 4(1), pp. 145-163, 2008.

[73] Brady, N. C. and R. R. Weil, "The nature and properties of soils". 13th ed., Pearson 2002. 
[74] Kena Kelbessa, "Effect of nitrogen rates and inter-row spacing on growth, yield and yield components of maize (Zea mays L.) at Nejo, Western Ethiopia". M.Sc. thesis, Haramaya University, Haramaya, Ethiopia, 2015.

[75] Eskandarnejada, S.S, Khorasani, S., Bakhtiaric, A.R., Heidarian. " Effect of row spacing and plant density on yield and yield components of sweet corn (Zea mays L.)". Journal of Crop Science, vol. 13(1), pp. 18-88, 2013.

[76] Rao S, Singh KK, Ali M., "Sulfur: A key nutrient for higher pulse production. Fertilizers News", vol. 46(10), pp. 37- 50, 2001.

[77] Dagne C. "Blended fertilizer effects on maize yield and yield components of Western Oromia, Ethiopia". Agriculture, Forestry and Fisheries vol. 5(5), pp. 151- 162, 2016.

[78] Maral, M., Mohammad, K.M., Ebrahim, A., Reza, K. D., and Hamid, R. B., "Effects of nitrogen fertilizer and plant density management in corn farming". Journal of Agricultural and Biological Science, vol. 2, pp. 133-137, 2012.

[79] Zamir, M.S.I., A.H., Ahmad, H.M.R., Javeed, T. Latif. "Growth and Yield Behaviors of Two Maize Hybrids (Zea mays L.) Towards Different Plant Spacing", Journal of Cercetări Agronomic in Moldova, vol. 146 , pp. $35, .2011$.

[80] Lemcoff, J. H., and R. S. Loomis., "Nitrogen and density influences on silk emergence, endosperm development, and grain yield of maize". Field Crops Research, vol. 38, pp 63-72, 1994.

[81] Jena, N., Vani, K.P., Rao, V.P. and Sankar, A.S., "Effect of nitrogen and phosphorus fertilizers on growth and yield of quality protein maize (QPM)", International Journal Science Research, vol. 4, pp.1839-1840. 2015 .

[82] Kogbe JOS, Adediran J. "Influence of nitrogen, phosphorus and potassium application on the yield of maize in the savanna zone of Nigeria"., African Journal of Biotechnology vol. 2(10) pp. 345-349, 2003.

[83] Schereer HW. "Sulfur in crop production", 2001.

[84] Orkaido Olte, Tamado Tana and Sheleme Beyene," Effect of nitrogen and Phosphorus fertilizer on yield \& yield components of maize (Zea mays L.) on black soil of Regede", 2004.

[85] Lakshmi, T.B., Prakash, H.C. and Sudhir, K.," Effect of different sources and levels of sulphur on the performance of rice and maize and properties of soils". Mysore Journal of Agricultural Sciences, vol. 44 (1), pp.79-88, 2010.

[86] Zamir, M.S.I., A.H., Ahmad, H.M.R., Javeed, T. Latif. "Growth and Yield Behaviors of Two Maize Hybrids (Zea mays L.) Towards Different Plant Spacing", Cercetări Agronomic in Moldova, vol. 146, pp. 35. 2011.

[87] Gobeze Yada Loha, Gert, M. C. and Van Rensburg, L. D., "Effect of Row Spacing and Plant Density on Yield and Yield Component of Maize (Zea mays L.) under Irrigation". Journal of Agricultural Science and Technology, vol. 2, pp. 263-271, 2012.

[88] Donatus, F. U. and Cynthia C.O., "Effects of poultry manure and plant population on soil properties and agronomic performance of sweet maize". International Journal of Applied Science and Technology, vol. 4(4) pp. 190-201, 2014.

[89] Jones, R. B. and J. W. Wendt, "Evaluation of the efficacy of Malai Tundulu phosphate rock for maize production CIMMYT". Literature update on maze.vol. 3 (6), pp.9, 1996.

[90] Degefa Gebissa." Effect of Nitrogen and Phosphorus Fertilizer Rates on Yield Components and Yield of Hybrid Maize (Zea mays L.) at Haramaya, Eastern Ethiopia". MSc Thesis, Haramaya University, Haramaya, Ethiopia, 2016.

[91] Zhao, F.G., Hawkesford M.J and Ms Grath S.P. "Sulfur assimilation and effects on yield and quality of wheat". Journal of Cereal science, vol.30, pp. 1-7, 1999.

[92] Housely, T. L., A. Kirleis, H. W. Ohm and F. L. Patherson,."Dry matter accumulation in soft red winter wheat seeds". Crop Science Journal, vol. 22, pp. 290-294, 1982.

[93] Hussain, N., Abuzar M. R., Sadozai G. U., Baloch M. S., Baloch A. A., Shah I. H., and Javaid T., "Effect of plant population densities on yield of maize". Journal of Animal and Plant Sciences, vol. 21(4), pp. 692695, 2011.

[94] Kebede Mulatu, Gezahgne Bogale, Benti Tolesa and Mosisa Worku.," Maize production trends and research in Ethiopia". In: Benti, T., Ransom, J.K. (eds.). Proceedings of the First National Maize Workshop of Ethiopia, 7 May. IAR, Addis Ababa, pp. 4-12, 1993.

[95] Ogunlela, V. B., G. M. Amoruwa and O. O. Olongunde., "Growth, yield components and micronutrient 
nutrition of field maize grown as affected by nitrogen fertilization and plant density". Journal of Agronomy, vol. 17, pp. 385-1314, 2005.

[96] Arif, M., I. Amin, M. T. Jan, I. Munir, K. Nawab, N. U. Khan and K. B. Marwat." Effect of plant population and nitrogen levels and methods of application on ear characters and yield of maize". Journal of Agriculture and Biology, vol. 42(3), pp. 1959-1967. 2010.

[97] Mukhtar, T., M. Arif, S. Hussain, M. Atif and K. Hussain, "Yield and yield components of maize hybrids as influenced by plant spacing". Journal of Agricultural research, vol. 50(1), pp. 63-67, 2012.

[98] Jordan, H., K. Laird, and D. Ferguson. "Growth rates and nutrient uptake by corn in a fertilizer-spacing experiment". Agronomy Journal, vol. 42, pp. 261-268, 1950.

[99] Samira M., A. Hussein, M.A. Haikel and M.A. El-Masry. "Effect of some preceding crops, hill spacing and nitrogen fertilization on yield attributes and grain yield of maize under reclaimed sandy soil conditions in East Delta". Proc. 8th Conf. Agron., Suez Canal Univ., Ismailia, Egypt, 28-29 Nov. pp. 174-18, 1998.

[100] Tisdale, S. L., Nelson, W. L. and Beaton, J. D. "Soil fertility and fertilizers"; Macmillan Publishing Company: New York, pp. 75-79, 1985.

[101] Mahmood, M.T., M. Maqsood, T. H. Awan and R. Sarwa," Effect of different levels of nitrogen and intra row plant spacing on yield and yield components of maize". Journal of agricultural science, vol. 38(2), pp. 35-38, 2001.

[102] Addis Tadesse and Hae Koo Kim. "Yield Related Traits and Yield of Quality Protein Maize (Zea mays L.) affected by Nitrogen Levels to achieve maximum yield in the Central Rift Valley of Ethiopia". Journal of Biology, Agriculture and Healthcare, vol. 5(15), pp. 141-145, 2015.

[103] Abdo Woyema., "Effect of different rates of nitrogen fertilizer on yield, yield related traits and quality of durum wheat (Triticum turgidum L.var. durum)". MSc.Thesis Haramaya University, Haramaya, Ethiopia, 2009.

[104] Pagano, E., and G.A. Maddonni, 2007. Intra-specific competition in maize: early established hierarchies differ in plant growth and biomass partitioning to the ear around silking. Field Crops Res., vol.101, pp. 306-320, 2007.

[105] Abebe Zeleke, Getachew Alemayehu and Yihenwu Ggbresilase,.,Effects of planting density and nitrogen fertilizer rate on yield and yield related traits of maize (Zea mays L.) in Northwestern Ethiopia". Advances in Crop Science and Technology, vol. 6(2), pp.15, 2012.

[106] Buah J., and Mwinkaara S, "Response of Sorghum to Nitrogen fertilizer and Plant density in the Guinea savanna Zone". Journal of Agronomy. vol. 8(4), pp. 124-130, 2009.

[107] Yayock

[108] Marschner P. "Rhizosphere biology. In: Marschner's Mineral Nutrition of Higher Plants (3rd Edition)”. pp. 369- 388, 2012.

[109] Qasim, M., H. Himayrull, and M. Subha. "Effect of increasing levels of phosphorus and seed rate on the economic yield of maize". Online Journal of Biological Sciences vol. 1, pp.40 -42, 2001.

[110] Olusegun, O. S. "Nitrogen (N) and Phosphorus (P) fertilizer application on maize (Zea mays L.) growth and yield at Ado-Ekiti, South-West, Nigeria”. American Journal of Experimental Agriculture, vol.6(1), pp. 22-29, 2015.

[112] Gahlout, B., Singh, R. and Lal, G. M. "Effect of levels of nitrogen and sulphur on growth and yield of maize (Zea mays L.)". Journal Maharashtra Agriculture University, vol. 35(1), pp.149-151, 2010.

[113] Moschler, W.W. and Martens, D.C."Nitrogen, Phosphorus, and Potassium Requirements in No-Tillage and Conventionally Tilled Corn". Soil Science Society of America, Proceedings, vol. 39, pp. 886-891, 1975.

[114] Sallah, P.Y.K., Mukakalisa, S., Nyombayire, A. and Mutanyagwa, P. "Response of two maize varieties to density and nitrogen fertilizer in the highland zone of Rwanda". Journal of Applied Biosciences, vol. 20, pp. $1194-1202,2009$.

[115] Huseyin Gozuben and Omer Konukan. "Nitrogen dose and plant density effects on popcorn grain yield". African Journal of Biotechnology, vol. 9(25), pp. 3828-3832, 2010.

[116] Cassman, K, Roberts, B and Bryant D., "Dry matter production and productivity of maize as influenced by residual fertilizer nitrogen and legume green manuring". Journal of Soil Science Society of America, vol.56, pp. 823-830, 2003. 